\title{
ANALYSIS OF ENERGY CONSUMPTION IN THE FACILITIES OF THE CIECHANÓW DAIRY COOPERATIVE
}

\author{
Marek Gugała', Krystyna Zarzecka' ${ }^{1}$, Krzysztof Kapela' $^{1}$, Anna Sikorska ${ }^{1}$ \\ 1 Siedlce University of Natural Sciences and Humanities, B. Prusa 14, 08-110 Siedlce, Poland, e-mail: gugala@ \\ uph.edu.pl; kzarzecka@ap.siedlce.pl
}

Received: 2015.03.02

Accepted: 2015.06.02

Published: 2015.07.01

\begin{abstract}
The work presents the analysis of electric energy consumption in individual buildings of the Ciechanów Dairy Cooperative in 2011. The plant includes a cool storage facility, a boiler house, a compression room and CIP (Cleaning In Place) stations. The plant manufactures liquid milk, cream, cheese, cottage cheese, cream cheese, butter and yoghurts. In 2011, the total electric energy consumption in the Cechanów Dairy Cooperative was $873114.0 \mathrm{kWh}$. The highest energy consumption (556430.0 kWh0 was recorded for the cooler (63.7\% of total consumption) and the lowest for CIP stations (33084.0 kWh). The average electric energy consumption in the Cooperative plant was $72759.5 \mathrm{kWh}$, the highest (104800.6 kWh) in November and the lowest (40 000.6 kWh) in March.
\end{abstract}

Keywords: electric energy, energy consumption, facilities, dairy cooperative.

\section{INTRODUCTION}

Energy productivity is a ratio of production to the energy which the production consumes. There are many energy sources available for enterprises to use [14]. According to Budny [3], demand of dairy processing plants is related to several kinds of energy, such as:

- heat energy,

- mechanic energy,

- electric energy,

- 'cold' energy,

- compressed air energy.

In manufacturing plants, consumption of each kind of energy can be divided into the following logistics sections: supply, distribution, production and storage. Each section is associated with an amount and value of energy consumed. Within the sections, energy consumption can be expressed quantitatively (in $\mathrm{kWh}$ ) or in terms of value (in PLN) depending on which data is available. 24-hour energy consumption and unit energy intensiveness depend mostly on a group of factors which are major contributors to the level of production mechanisation and technical condi- tion, and a group of other factors specific to individual types of dairy enterprises [14].

According to Mierzejewska [9], around 80\% of energy consumed by dairy industry is the energy produced during fuel combustion and processed to steam and warm water. The remaining energy is electric energy necessary to maintain the operations of the production lines, cooling systems, ventilation and lighting.

According to guidelines for the dairy industry published in the best available techniques (BAT), significant electric energy consumption for the whole dairy plant is generated by compressors of coolers as well as surface aerators in the plant's sewage treatment facility. Compared with other European countries, in Poland too much energy is used for heating the buildings constructed without paying enough attention to the ecological and economic aspect of energy consumption [11]. According to the best available techniques [1], it is necessary for dairy plants to undertake pro-environment actions specified in Best Available Technique Reference Documents (BREFs). Integrated licences refer to possibilities of limiting energy consumption by means of direct and indirect 
methods. Direct methods refer to actions directly connected with electric equipment such as checking the choice of engine power, load and work time, an application of modern highly efficient equipment, as well as energy-efficient lighting. Indirect methods of reducing electric energy consumption include all technical and management actions which have come to be known as rules of 'good manufacturing practice', such as good insulation of low temperature buildings, an application of automatically operated light switches, tight technological and technical systems and monitoring, setting target indicators of electric energy consumption and analysis of meeting of these standards, training of employees and rewarding efficient energy consumption [4, 7].

\section{PAPER OBJECTIVE AND SCOPE}

Data obtained from the Ciechanów Dairy Cooperative was used to analyse electric energy consumption in the following facilities of the plant: a boiler house, a compression room, a cooling facility and CIP (Cleaning In Place) stations. Energy consumption was analysed for individual months.

\section{RESULTS AND DISCUSSION}

According to Trojanowska [13], the indicator of electric energy consumption for dairy enterprises ranges from 55 to $88 \mathrm{kWh} /$ th litres of processed milk, an average being $74 \mathrm{kWh} / \mathrm{th}$ of milk, and the value of the indicator is associated with weather conditions. The average electric energy consumption in the facilities of Ciechanów Dairy Cooperative in 2011 was $72759.5 \mathrm{kWh}$. The highest consumption was in November and the lowest in March, 104800.6 and $40000.6 \mathrm{kWh}$, respectively (Figure 1).

Branches of food industry where pipe-based systems are used (dairy industry, brewing industry, manufacturing of edible fats and oils), CIP cleaning systems are applied. It means technological systems are cleaned using cleaning stations with forced flow of a cleaning agent in the system [12]. A CIP station is made up of tanks with mixing units and heaters (for cleaning chemicals, water, disinfecting liquids), pumps, a system of pipes with valves and a control unit. To clean, a CIP station is connected to the technological installation and used to reinforce the flow of cleaning, flushing and disinfecting liquids through pipes and technological equipment. CIP stations are basic equipment for cleaning processing equipment in the food industry [5]. Cleaning and disinfection are energy-consuming and require the use of various products for cleaning of both equipment and production surfaces to make sure processing takes place in appropriate conditions [9]. High energy consumption is associated with the amount and temperature of water used during the cleaning process [6]. At the Ciechanów Dairy Cooperative, a gradual increase in electric energy consumption was recorded for CIP stations from March (1500.6 kWh, the lowest energy consumption in 2011) to June $(3800.6 \mathrm{kWh})$, being the highest in August (4400.0 kWh) (Figure 2).

The use of heat energy and cooling processes is a necessary component of technological process in food industry. In particular, cooling

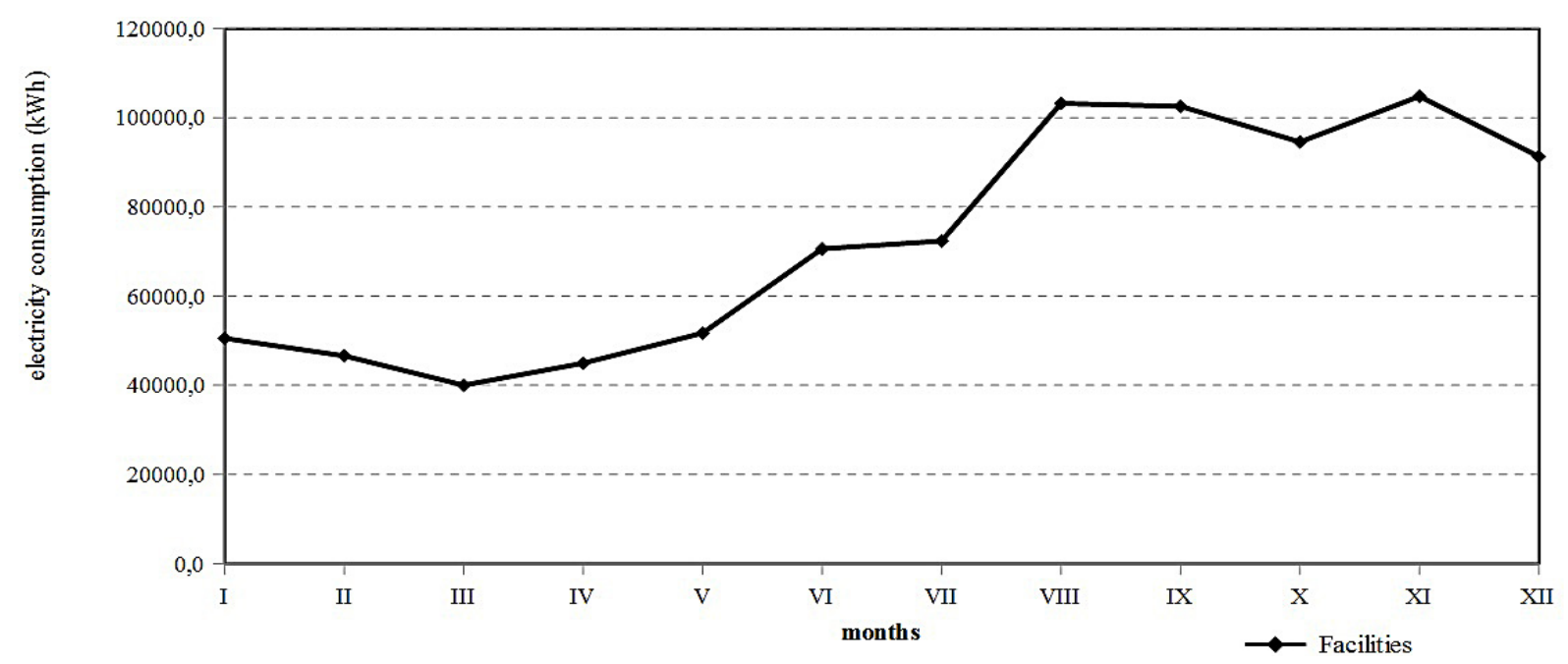

Figure 1. Mean monthly electricity consumption (kWh) in facilities of the Ciechanow Dairy Processing Plant in 2011 


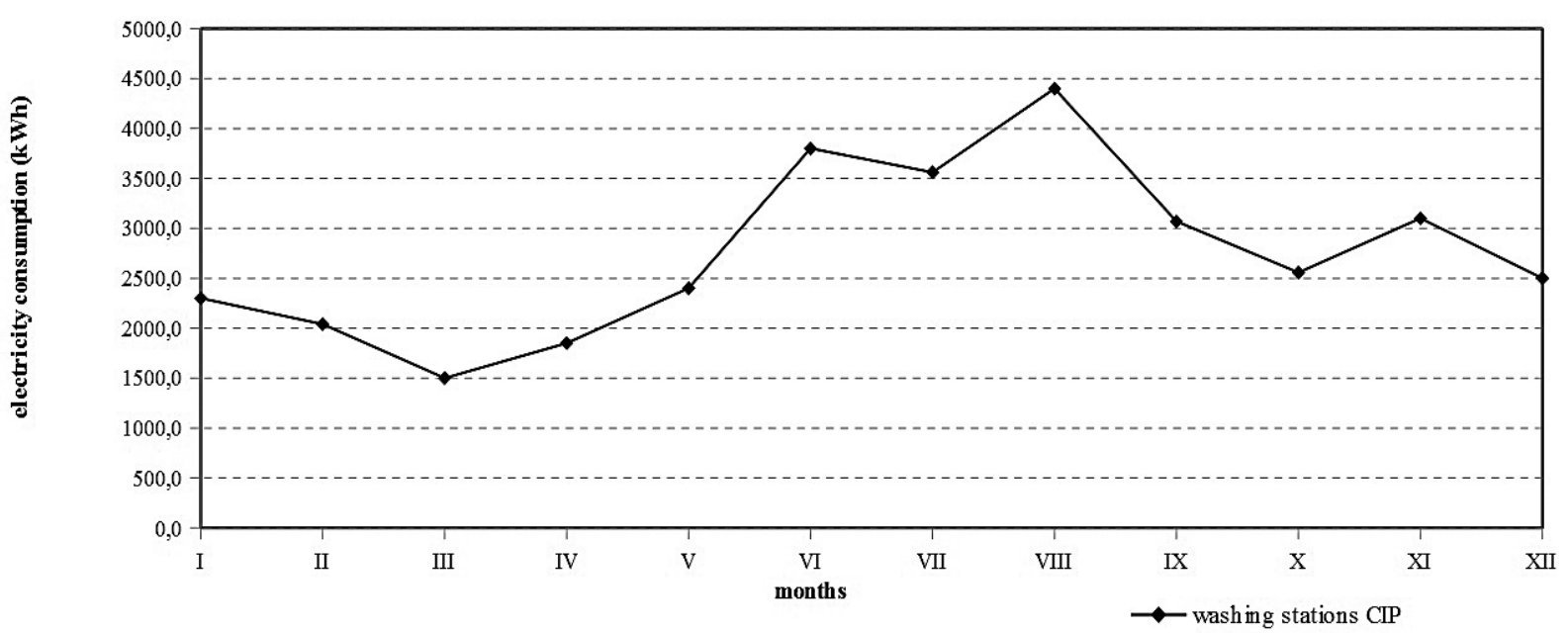

Figure 2. Mean monthly electricity consumption $(\mathrm{kWh})$ in the Ciechanow Dairy Processing Plant: washing stations CIP in 2011

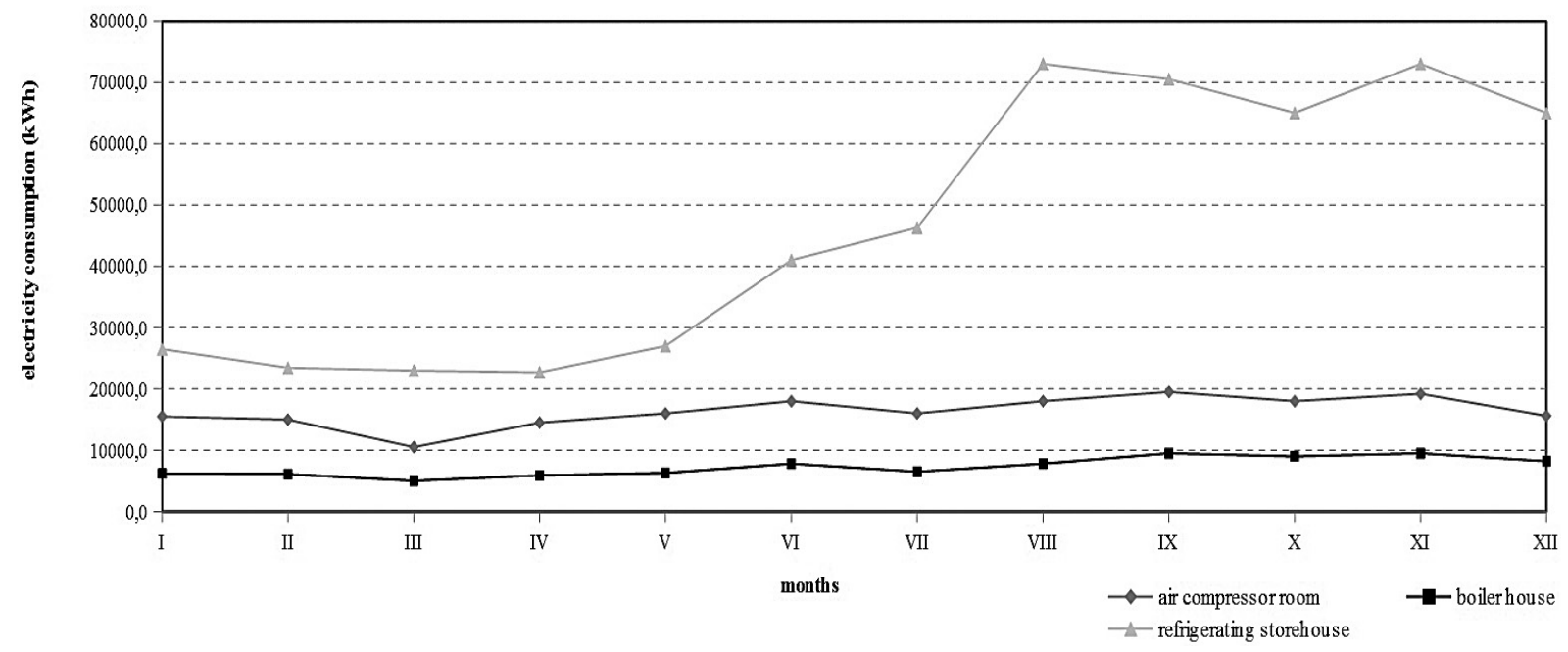

Figure 3. Mean monthly electricity consumption (kWh) in the Ciechanow Dairy Processing Plant: refrigerating storehouse, air compressor room, boiler house in 2011

processes have a significant effect on production quality [2]. Energy consumption in the cool storage facility of Ciechanów Dairy Cooperative was very high. The least energy was consumed in April (22 700.0 kWh). Then, energy consumption increased from $27000.0 \mathrm{kWh}$ in May to $73000.0 \mathrm{kWh}$ in August. High energy consumption (73 $000.0 \mathrm{kWh}$ ) was also recorded in November. Studies conducted by Marks [8] in selected dairy plants demonstrated that energy consumption was the highest in a compression room. It is because the equipment there (ammonia compressor in particular) works all the time and is very powerful. Energy consumption in the compression room of the Ciechanów Dairy Cooperative was very high, being the highest (19 500.0 kWh) in September and November and the lowest in March (10 500.0 kWh)
Electric energy consumption in the boiler house was the lowest $(9500.0 \mathrm{kWh})$ in September and November and the highest in January and February (6100.0 kWh) (Figure 3).

\section{CONCLUSION}

The analysis demonstrated that the highest energy consumption at the Ciechanów Dairy Cooperative was in the cooling facility; it accounted for $63.7 \%$ of the total electric energy consumption recorded for all the facilities of the plant. The cooling facility followed the compression room. Energy consumption there was 195800.0 $\mathrm{kWh}$ in 2011. The CIP stations contributed least (33 $084.0 \mathrm{kWh}$ ) to energy consumption of the plant as a whole. 


\section{REFERENCES}

1. BAT - Best Available Techniques, 2005. Najlepsze dostępne techniki. Wytyczne dla branży mleczarskiej. Ministerstwo Środowiska, 1-46.

2. Bieranowski J., Klonowski A. 2005. Model sytemu skojarzonego źródła energii cieplnej w zakładzie przemysłu rolno-spożywczego. Inżynieria Rolnicza, 6 (66), 33.

3. Budny J. 1993. Zakład mleczarski jako użytkownik i wytwórca energii, cz. II. Przegląd Mleczarski 5, 17-18.

4. Budny J., Turowski J. 2005. Pozwolenie zintegrowane - energia elektryczna. Przegląd Mleczarski $6,18-21$.

5. Diakun J., Mierzejewska S. 2004. Analiza techniczna stacji CIP oferowanych na polskim rynku. Postępy Techniki Przetwórstwa Spożywczego, 2, 55-58.

6. Diakun J., Mierzejewska S. 2012. Energia w funkcji skuteczności mycia w systemie CIP. Inżynieria Rolnicza, 3(138), 23-28.

7. Hadryjańska B. 2008. Pro-ecological activities of dairy firms in Wielkopolska as a factor of their competitive position. Journal of Agribusiness and Rural Development, 4(10), 25-35.
8. Marks N., Gut M. 2007. Nakłady energetyczne w procesie produkcji mleka spożywczego i przetworów mlecznych. Inżynieria Rolnicza, 6(94), 155.

9. Mierzejewska S., Diakun J. 2011. Energia w procesie mycia rurociągów w systemie CIP. Inżynieria i Aparatura Chemiczna, 50(1), 25.

10. Rostek M., Knosala R. 2013. Koncepcja oceny wpływu działań logistycznych na produktywność przedsiębiorstwa. In: Knosala R. (Ed.) Innowacje w zarządzaniu i inżynierii produkcji, Oficyna Wydawnicza PTZP, Opole.

11. Rutkowska G., Wojnowski D. 2014. Analiza wariantów termomodernizacji budynku mieszkalnego w kontekście optymalnego zapotrzebowania energetycznego. Inżynieria Ekologiczna, 37, 162.

12. Tamime A.Y. 2008. Cleaning - in-Place: Dairy, Food and Beverange Operations. Blackwell Publishing Ltd Oxfort.

13. Trojanowska M. 2010. Analiza zapotrzebowania na moc i energię elektryczną w zakładzie mleczarskim. Journal of Research and Applications in Agricultural Engineering, 55(2), 116.

14. Wojdalski J., Dróżdż B. 2006. Podstawy analizy energochłonności produkcji zakładów przemysłu rolno-spożywczego. MOTROL, 8A, 302-303. 